\title{
Rituximab for PTLD of the CNS: Is It a 'No-Brainer'?
}

\author{
Ran Reshef Donald E. Tsai \\ Abramson Cancer Center, University of Pennsylvania, Philadelphia, PA, USA
}

In this issue of ONKOLOGIE, Kordelas and his colleagues report 2 cases of central nervous system (CNS) involvement with post-transplantation lymphoproliferative disorder (PTLD) which appeared following allogeneic stem-cell transplantation (SCT) and was successfully treated with the anti-B-cell monoclonal antibody rituximab [1]. This case report illustrates two of the greatest success stories in immunotherapy of the last few decades. The first one is allogeneic SCT, now used for more than 25,000 patients annually worldwide. PTLD, a well characterized entity following solid-organ transplants, is a rare event after allogeneic SCT, more commonly seen when a T-cell depleted graft is used [2]. Reducing immunosuppression is highly effective in eradicating PTLD in solid-organ transplant recipients. Approximately half of the patients will enter remission and remain free of disease using reduction of immunosuppression only, exemplifying the power of the immune system in tumor surveillance and eradication of tumor cells. In stem-cell transplant recipients, reduction of immunosuppression is often not an option and therapy requires other modalities. This leads us to another major success story in cancer immunotherapy - the advent of monoclonal antibodies for B-cell malignancies.

PTLD encompasses a spectrum of lymphoid proliferative disorders ranging from benign polyclonal hyperplasia to malignant monoclonal neoplasms which resemble lymphomas. The association with Epstein-Barr Virus (EBV) is well-described [3] and PTLD can be regarded as the acquired equivalent of a congenital immune deficiency, known as X-linked lymphoproliferative disorder, which places young children at increased risk for a severe and often lethal course of primary EBV infection. Still, 10-20\% of all PTLD cases are not associated with EBV infection.

Primary CNS PTLD is uncommon. Leblond reported on 5 patients with primary CNS involvement in a series of 61 patients with PTLD [4]. CNS involvement was associated with a nega- tive impact on survival and poor response to reduction of immunosuppression. An earlier report from Penn and Porat showed CNS involvement in 22\% among a large series of 1332 patients with PTLD but only half of them had primary CNS disease. Dismal prognosis was seen in their series as well [5]. Rituximab is a chimeric $\mathrm{IgG}_{1}$ anti-CD20 monoclonal antibody. Multiple studies have shown its utility in PTLD, usually after reduction of immunosuppression has failed or could potentially result in life-threatening graft failure. Several case series and phase II clinical trials demonstrated overall response rates ranging between 44 and $75 \%$ and complete response rates of 35-69\% [6-8]. Several obstacles limit the activity of rituximab in CNS disease. First, it crosses the blood-brain barrier very poorly due to its high molecular weight of $145 \mathrm{kDa}$. Pharmacokinetic studies in patients with lymphoma showed that the concentration in the cerebrospinal fluid (CSF) is approximately 1000-fold lower compared to serum [9]. Second, out of three presumptive mechanisms of action for rituximab (induction of apoptosis, antibody-dependent cellular cytotoxicity and complement-mediated cytotoxicity), the last two are not thought to work efficiently in brain tissue or in the CSF.

Small case series utilizing rituximab for CNS lymphoma were published in 2004. Schulz reported that intrathecal or intraventricular administration of rituximab was well tolerated and resulted in good response of leptomeningeal disease but very little response in patients with parenchymatous involvement [10]. The efficacy of i.v. rituximab was questionable in that report as well as others, where rituximab was given in conjunction with temozolomide [11]. A recent multicenter trial incorporated rituximab in combination therapy for primary CNS lymphoma, resulting in a $77 \%$ complete remission rate. Compared with historical controls, the addition of rituximab did not improve response rates but toxicity was higher, especially neutropenia [12]. Based on the literature thus far, it is doubtful that rituximab has a major role - if any - in the treatment of

\section{KARGER}

Fax +497614520714

Information@Karger.de

www.karger.com
(C) 2008 S. Karger GmbH, Freiburg

Accessible online at:

www.karger.com/onk
Donald E. Tsai, MD, PhD

Abramson Cancer Center, University of Pennsylvania

16 Penn Tower

3400 Spruce St., Philadelphia PA 19104, USA

Tel. +1 215 614-0037, Fax -4064

detsai@mail.med.upenn.ed 
CNS lymphoma. It is possible that its main role is in treating occult disease outside the brain.

What about rituximab for PTLD involving the CNS? The authors review a handful of case reports, in which rituximab was combined with other forms of therapy. The case report in this issue of ONKOLOGIE suggests that rituximab monotherapy works just as well. Of note, the first patient in this report had his immunosuppression reduced, which precludes estimation of the true contribution of rituximab to his clinical improvement. This illustrates how difficult it is to evaluate therapies in isolation when a multi-modality approach is used, which is often the case in a PTLD patient.

So what should be our approach to PTLD involving the CNS? Reduction of immunosuppression, if the patient's life is not threatened by a rapidly progressive disease or a failing allograft, should always be the first step. PTLD has an exquisite response to restoration of immune function by cutting down immunosuppressive therapy and responses can be seen regardless of stage, location and morphologic 'aggressiveness' of the tumor. If a significant response was not achieved with reduction of immunosuppression, choice of additional therapy depends on the patient's performance status and organ function. Rituximab is a legitimate and non-toxic choice if we predict that the patient might not tolerate systemic chemotherapy and/or radiotherapy. Kordelas and his colleagues demonstrate success of this approach in this case report but the true efficacy is unknown. The recommended dose of rituximab is also undetermined and some preliminary data suggests that higher doses can overcome the barrier in crossing into the CSF. All these questions should better be answered in the context of prospective clinical trials before determining the exact role of rituximab in B-cell neoplasms of the brain.

\section{References}

1 Kordelas L, Trenschel R, Koldehoff M, Elmaagacli A, Beelen DW: Successful treatment of EBV PTLD with CNS lymphomas with the monoclonal antiCD20 antibody rituximab. Onkologie 2008;31: DOI: $10.1159 / 000165057$.

-2 Shapiro RS, McClain K, Frizzera G, Gajl-Peczalska KJ, Kersey JH, Blazar BR, Arthur DC, Patton DF Greenberg JS, Burke B, et al.: Epstein-Barr virus associated B cell lymphoproliferative disorders following bone marrow transplantation. Blood 1988; 71:1234-1243.

3 Thorley-Lawson DA, Gross A: Persistence of the Epstein-Barr virus and the origins of associated lymphomas. N Engl J Med 2004;350:1328-1337.

4 Leblond V, Dhedin N, Mamzer Bruneel MF, Choquet S, Hermine O, Porcher R, Nguyen Quoc S, Davi F, Charlotte F, Dorent R, Barrou B, Vernant JP, Raphael M, Levy V: Identification of prognostic factors in 61 patients with posttransplantation lymphoproliferative disorders. J Clin Oncol 2001;19: 772-778.
5 Penn I, Porat G: Central nervous system lymphomas in organ allograft recipients. Transplantation 1995;59:240-244.

6 Elstrom RL, Andreadis C, Aqui NA, Ahya VN, Bloom RD, Brozena SC, Olthoff KM, Schuster SJ, Nasta SD, Stadtmauer EA, Tsai DE: Treatment of PTLD with rituximab or chemotherapy. Am J Transplant 2006;6:569-576.

7 Svoboda J, Kotloff R, Tsai DE: Management of patients with post-transplant lymphoproliferative disorder: The role of rituximab. Transpl Int 2006;19: 259-269.

8 Choquet S, Leblond V, Herbrecht R, Socie G, Stoppa AM, Vandenberghe P, Fischer A, Morschhauser F, Salles G, Feremans W, Vilmer E, Peraldi MN, Lang P, Lebranchu Y, Oksenhendler E, Garnier JL, Lamy T, Jaccard A, Ferrant A, Offner F, Hermine O, Moreau A, Fafi-Kremer S, Morand P, Chatenoud L, Berriot-Varoqueaux N, Bergougnoux L, Milpied $\mathrm{N}$ : Efficacy and safety of rituximab in B-cell posttransplantation lymphoproliferative disorders: Results of a prospective multicenter phase 2 study. Blood 2006;107:3053-3057.
9 Harjunpaa A, Wiklund T, Collan J, Janes R, Rosenberg J, Lee D, Grillo-Lopez A, Meri S: Complement activation in circulation and central nervous system after rituximab (anti-CD20) treatment of B-cel lymphoma. Leuk Lymphoma 2001;42:731-738.

10 Schulz H, Pels H, Schmidt-Wolf I, Zeelen U, Germing U, Engert A: Intraventricular treatment of relapsed central nervous system lymphoma with the anti-CD20 antibody rituximab. Haematologica 2004;89:753-754.

11 Wong ET, Tishler R, Barron L, Wu JK: Immunochemotherapy with rituximab and temozolomide for central nervous system lymphomas. Cancer 2004;101:139-145.

12 Shah GD, Yahalom J, Correa DD, Lai RK, Raizer JJ, Schiff D, LaRocca R, Grant B, DeAngelis LM, Abrey LE: Combined immunochemotherapy with reduced whole-brain radiotherapy for newly diagnosed primary CNS lymphoma. J Clin Oncol 2007; 25:4730-4735. 